\section{EREM 74/3}

Journal of Environmental Research, Engineering and Management Vol. 74 / No. 3 / 2018 pp. $80-86$ DOI 10.5755/j01.erem.74.3.21069 (C) Kaunas University of Technology
Rhizospheric Bacteria for Destruction of Nitrochloroaromatic Compounds

\title{
Rhizospheric Bacteria for Destruction of Nitrochloroaromatic Compounds
}

\author{
lungin 0., Govorukha V., Tashyrev 0.
}

Zabolotny Institute of Microbiology and Virology of the National Academy of Sciences of Ukraine, 03143, Kyiv, Zabolotny str. 154, Ukraine

Corresponding author: olga.suslova11@gmail.com

lungin O., Zabolotny Institute of Microbiology and Virology of the National Academy of Sciences of Ukraine, Ukraine

Nitrochloroaromatic compounds (NCAC) are among the most toxic for humans and cause different disorders when they get into the food chain through agricultural soils with wastewater from enterprises of organic synthesis. Microorganisms were shown to be a successful way of destruction of such compounds. The aim of our study was to check the resistance and the ability of 17 wheat rhizosphere bacterial strains to degrade NCAC. Rhizospheric strains were shown to be highly resistant to 1-nitro-4-chlorobenzene (NCB) - the representative compound that combines negative effects of a nitro group, chlorine and an aromatic ring. The level of resistance was up to $300 \mathrm{mg} / \mathrm{L}$ of NCB . The studied strains were able to degrade it to end products $\left(\mathrm{CO}_{2}, \mathrm{H}_{2} \mathrm{O}\right)$. Moreover, 10 of 17 bacterial strains were able to use 1-nitro-4-chlorobenzene as an additional source of carbon and energy. These promising results could be used in rhizoremediation biotechnologies.

Keywords: rhizosphere, bacteria, nitrochloroaromatics, degradation.

\section{Introduction}

One of the main sources of environmental pollution is enterprises of organic synthesis. The composition of their wastewater includes aromatic compounds, nitroorganics, organochlorine, etc. Particularly dangerous are xenobiotics, which include an aromatic ring, a nitro group and chlorine. Nitrochloroaromatic compounds (NCACs) are originally synthetic and used in production of medicines, herbicides, pesticides, dyes, corrosion inhibitors, etc. (Fohua \& Siqing, 2011). NCACs are hazardous to humans and animals due to their haemato-, immune, genome, hepato-toxicity, nephrite-toxicity and carcinogenicity (Kovacic \& Somanathan, 2014). Nitrochloroaromatic compounds are rapidly absorbed by the skin, and 
mucous membranes of the gastrointestinal and the respiratory tract; they are distributed in the tissues of the body, mainly in blood cells, skeletal muscle, liver and kidneys. Representatives of the NCACs are nitrochlorobenzenes, nitrochlorophenols and nitrochlorobenzenic acids. These compounds can enter industrial water streams and pollute soils. Because of the toxic impact on humans and occasions of NCACs to pollute agricultural soils it is necessary to find out possible ways to neutralise these compounds.

They can be removed from the environment by (bio)degradation or by (bio)transformation in 3 different ways:

a reduction of the nitro group;

b chlorine replacement (dehalogenation);

c aromatic ring reduction, hydroxylation and subsequent cycle cleavage.

The prolonged presence of NCACs in soils and water has a negative impact on flora and fauna. Due to high toxicity, NCACs are listed as major pollutants according to the documentation of the US Environmental Protection Agency (Rieger et al., 2002).

Bacteria have a broad spectrum of mechanisms to inactivate toxic compounds. Moreover, there is evidence that bacteria can use NCACs as a sole carbon and energy source (Katsivela et al., 1999). The example of such bacteria is Burkholderia sp. SJ98 that utilises 2-chloro-4-nitrophenol as the sole carbon, nitrogen and energy sources (Pandey et al., 2011).

In most cases, the initial stages of NCACs occur in the presence of an additional carbon and energy source used by microbes to transform (i.e., change the structure) xenobiotics. This leads to a reduction of toxicity of a xenobiotic, increases its availability to microorganisms and ensures its further destruction. The process of destruction starts with the reduction of a nitro group to an amino group, subsequent deamination, reductive dehalogenation and cleavage of an aromatic ring. This causes mineralisation of the compound, i.e., transformation of NCACs into inorganic compounds: carbon dioxide and water (Tomei et al., 2006).

Such microbial degradation is significantly influenced by the position of chlorine and nitro groups in the benzene ring. Compounds containing a nitro group and chlorine in the para-position are more stable compared with compounds with ortho- and meta-positions of the functional groups. All these compounds - o-nitrochlorobenzene, $m$-nitrochlorobenzene and $p$-nitrochlorobenzene - are isomeric. Enzymes that destroy the ortho-compounds are non-specific to the meta- and para-compounds and vice versa. The presence of several atoms of chlorine greatly increases the stability of the benzene ring. Cleavage of the carbon-halogen bond is the critical step in degradation of chloroaromatics (Arora \& Bae, 2014a).

Thus, microorganisms are able to transform nitrochloroaromatic toxic persistent compounds to non-toxic compounds (alcohols, etc.) and then to endproducts $\left(\mathrm{CO}_{2}, \mathrm{H}_{2} \mathrm{O}\right)$. The rate of transformation depends on: i) the number of chlorine atoms; ii) the structure of a compound (position of the nitro group and chlorine); iii) fermentative activity of a microorganism; and iv) the presence of an extra donor of electrons, etc.

In bioremediation of soil, biodegradation can be enhanced by making conditions favourable for the catabolic process. Plants in phytoremediation of hydrocarbon contaminants have been proposed to improve degradation conditions in soil, and some improvement in biodegradation has been observed in plant microcosms/microecosystems (Suslova et al., 2015). Plant-associated microbes, especially in the root zone, potentially play a central role in rhizoremediation (White et al., 2006).

We assume that rhizospheric bacteria can survive under pressure of high concentrations of NCACs and heavy metals. We also suggest that these bacteria can overcome the toxic effect of nitrochloroaromatic compounds. We chose p-nitrochlorobenzene (1-nitro-4-chlorobenzene) as a model organic persistent xenobiotic for our studies.

\section{Methods}

The objects of study were chemoorganotrophic aerobic bacterial strains (17) isolated from winter wheat rhizosphere cultivated in the presence of cadmium $(100 \mu \mathrm{M})$. Colony morphotypes obtained on the agar medium from maximum 10 -fold dilutions of rhizospheric soil were reisolated 3 times to check the purity of the culture and to get single colonies. All strains were identified by $16 \mathrm{~S}$ sequencing by Thermo Fisher 
Scientific Co in the frame of CRDF Global Ukraine-USA Grant OISE 16-62773-0.

Determination of resistance to NCB. Strain resistance to NCB was determined in a liquid medium (NB, HiMedia Ltd.) in close vials with a concentration gradient of the xenobiotic (50-300 mg/L). The controlled parameter was biomass growth determined photocolorimetrically by optical density of the liquid culture on Multiskan Ascent (Thermo 52 Labsystems, Finland) $(\lambda$ $=540 \mathrm{~nm}$ ). The inoculated medium without the xenobiotic was used as a growth control.

Determination of the strain ability to degrade the xenobiotic. Microorganisms are cultured in NCB concentration gradient $(50-300 \mathrm{mg} / \mathrm{L}$ ) in an NB medium during 3 days. The concentration of NCB and chloroaniline (ClA) was determined by mass spectrometry using gas chromatography-mass-spectrum system Agilent 6890N/5973inert (capillary column HP-5MS ; J\&W Scientific, USA). The parameters were as follows: gas carrier - helium; initial column temperature $-150^{\circ} \mathrm{C}$; final column temperature $-250^{\circ} \mathrm{C}$; temperature gradient $-4^{\circ} \mathrm{C} / \mathrm{min}$; interface temperature $-280^{\circ} \mathrm{C}$; type ionization - electron impact; and ionization energy - $70 \mathrm{eV}$. For this, the culture liquid was centrifuged $(1700 \mathrm{~g}, 15 \mathrm{~min})$. Hexane $(0.5 \mathrm{~mL})$ was added to the supernatant $(0.7 \mathrm{~mL})$ and suspended for $3 \mathrm{~min}$. Next, the suspension was centrifuged $(360 \mathrm{~g}, 10 \mathrm{~min}$ ) to separate phases. Thereafter, hexane was collected $(0.4 \mathrm{~mL})$ and analysed. Data processing of gas chromatography-mass spectrometry analysis was performed using the computer programme ChemStation and the integrated database of mass spectra NIST 02.

All the experiments were run thrice. The experimental data were analysed by statistical methods in Excel, $P \leq 0.05$.

\section{Results and Discussion}

The data of NCB influence on the growth level of bacterial strains are presented below (Table 1). All studied strains were resistant to NCB even up to $300 \mathrm{mg} / \mathrm{L}$.

\section{Table 1}

The influence of NCB on the bacterial growth level

\begin{tabular}{|c|c|c|c|c|c|c|}
\hline \multirow{2}{*}{ № } & \multirow{2}{*}{ Stains } & \multicolumn{5}{|c|}{ NCB concentration, $\mathrm{mg} / \mathrm{L}$} \\
\hline & & 0 & 50 & 100 & 200 & 300 \\
\hline 1 & 2 & 3 & 4 & 5 & 6 & 7 \\
\hline 1 & Brevundimonas vesicularis & $1.38 \pm 0.22$ & $1.16 \pm 0.03$ & $1.15 \pm 0.036$ & $0.65 \pm 0.056$ & $0.36 \pm 0.01$ \\
\hline 2 & Arthrobacter oxidans & $0.101 \pm 0.003$ & $0.419 \pm 0.02$ & $0.323 \pm 0.01$ & $0.44 \pm 0.03$ & $0.595 \pm 0.025$ \\
\hline 3 & Brachybacterium paraconglomeratum & $0.085 \pm 0.008$ & $0.34 \pm 0.007$ & $0.347 \pm 0.01$ & $0.345 \pm 0.03$ & $0.37 \pm 0.026$ \\
\hline 4 & Variovorax paradoxus & $0.07 \pm 0.004$ & $0.36 \pm 0.018$ & $0.29 \pm 0.004$ & $0.2 \pm 0.008$ & $0.175 \pm 0.006$ \\
\hline 5 & Arthrobacter sulfureus & $0.34 \pm 0.004$ & $0.543 \pm 0.023$ & $0.67 \pm 0.108$ & $0.62 \pm 0.007$ & $0.59 \pm 0.052$ \\
\hline 6 & Pseudomonas lini & $0.73 \pm 0.004$ & $0.62 \pm 0.04$ & $0.635 \pm 0.03$ & $0.49 \pm 0.007$ & $0.39 \pm 0.059$ \\
\hline 7 & Sphingomonas sp. & $0.07 \pm 0.004$ & $0.479 \pm 0.009$ & $0.35 \pm 0.12$ & $0.45 \pm 0.004$ & $0.21 \pm 0.008$ \\
\hline 8 & Providencia rettgeri & $0.715 \pm 0.015$ & $1.26 \pm 0.017$ & $1.25 \pm 0.025$ & $1.1 \pm 0.045$ & $0.97 \pm 0.031$ \\
\hline 9 & Sphingomonas witflariensis & $1.23 \pm 0.124$ & $1.19 \pm 0.054$ & $1.18 \pm 0.068$ & $1.05 \pm 0.036$ & $0.94 \pm 0.04$ \\
\hline 10 & Rhodococcus erythropolis & $0.61 \pm 0.044$ & $1.06 \pm 0.27$ & $0.93 \pm 0.09$ & $1.48 \pm 0.053$ & $1.64 \pm 0.09$ \\
\hline 11 & Arthrobacter sp. & $0.35 \pm 0.016$ & $0.123 \pm 0.005$ & $0.104 \pm 0.004$ & $0.055 \pm 0.002$ & $0.039 \pm 0.003$ \\
\hline 12 & Pseudomonas putida & $0.41 \pm 0.002$ & $0.887 \pm 0.058$ & $1.04 \pm 0.01$ & $0.96 \pm 0.39$ & $0.57 \pm 0.06$ \\
\hline 13 & Achromobacter xylosoxidans & $0.69 \pm 0.04$ & $1.19 \pm 0.06$ & $1.18 \pm 0.01$ & $1.13 \pm 0.08$ & $1.03 \pm 0.106$ \\
\hline 14 & Achromobacter xylosoxidans & $0.51 \pm 0.07$ & $1.28 \pm 0.05$ & $1.38 \pm 0.16$ & $1.23 \pm 0.09$ & $1.24 \pm 0.09$ \\
\hline 15 & Ensifer adhaerens & $0.66 \pm 0.01$ & $0.73 \pm 0.08$ & $0.97 \pm 0.04$ & $0.77 \pm 0.13$ & $0.71 \pm 0.08$ \\
\hline 16 & Cupravidus gilardii & $0.34 \pm 0.02$ & $0.59 \pm 0.01$ & $0.56 \pm 0.01$ & $0.57 \pm 0.007$ & $0.55 \pm 0.02$ \\
\hline 17 & Cupravidus gilardii & $0.56 \pm 0.05$ & $1.55 \pm 0.13$ & $1.36 \pm 0.05$ & $1.17 \pm 0.02$ & $0.82 \pm 0.004$ \\
\hline
\end{tabular}


Unexpectedly, several peculiarities about the impact of NCB on studied strains were revealed. First, all strains could multiply to achieve OD parameters at more than 0.1 point even in the presence of $300 \mathrm{mg} / \mathrm{L}$ and were highly adaptive to NCB. There were 3 types of answers to NCB presence. The first was a classical answer of bacteria to toxic compound presence. The OD parameter inhibited with the increasing concentration of NCB (Fig. 1).

Fig. 1

The first type of a bacterial response to NCB presence

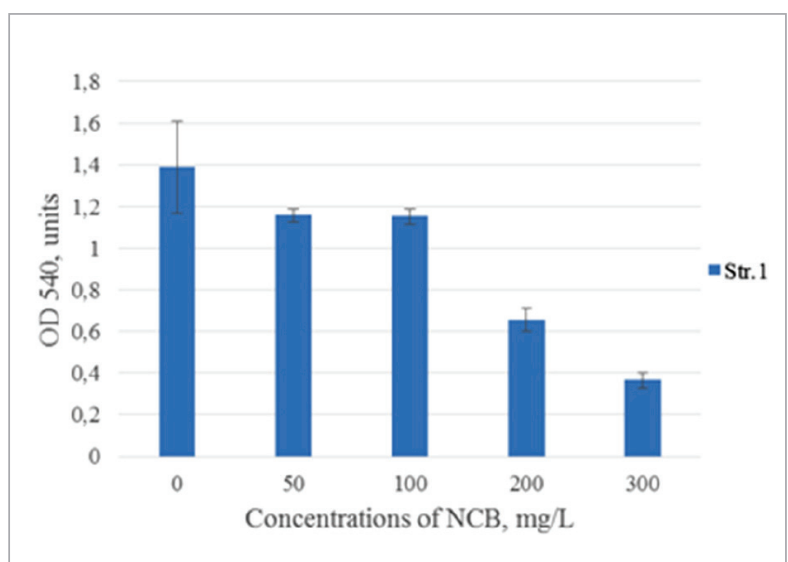

This type of an answer was presented by strains 1, 6, 9 and 11 , i.e., Brevundimonas vesicularis, Pseudomonas lini, Sphingomonas witflariensis, Arthrobacter sp., respectively.

The second type of answer was described as follows. Strains provided higher $\mathrm{OD}$ in the presence of NCB

Fig. 2

The second type of a bacterial response to NCB presence

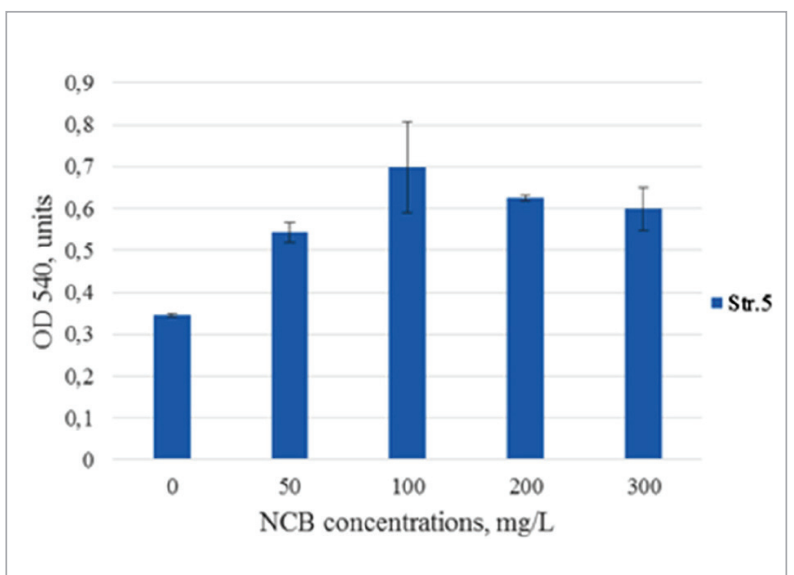

compared with control (without NCB). For example, Arthrobacter oxidans Str. 2 or Arthrobacter sulfureus Str. 5 produce OD 2-4 times higher in the presence of $50-300 \mathrm{mg} / \mathrm{L}$ of NCB than in the control. It was the evidence that these strains could use NCB as a source of carbon and energy.

This type of an answer was presented by more than a half of the studied strains: 2, 3, 5, 7, 13, 14 and 16, i.e., Arthrobacter oxidans, Brachybacterium paraconglomeratum, Arthrobacter sulfureus, Sphingomonas sp., and Achromobacter xylosoxidans, respectively. There was one more variation in this type of an answer. It was shown as increasing OD in the presence of NCB compared with the control. However, the higher the concentration of NCB, the lower the growth increase was observed (Fig. 3).

\section{Fig. 3}

The variation in the second type of a bacterial response to NCB presence

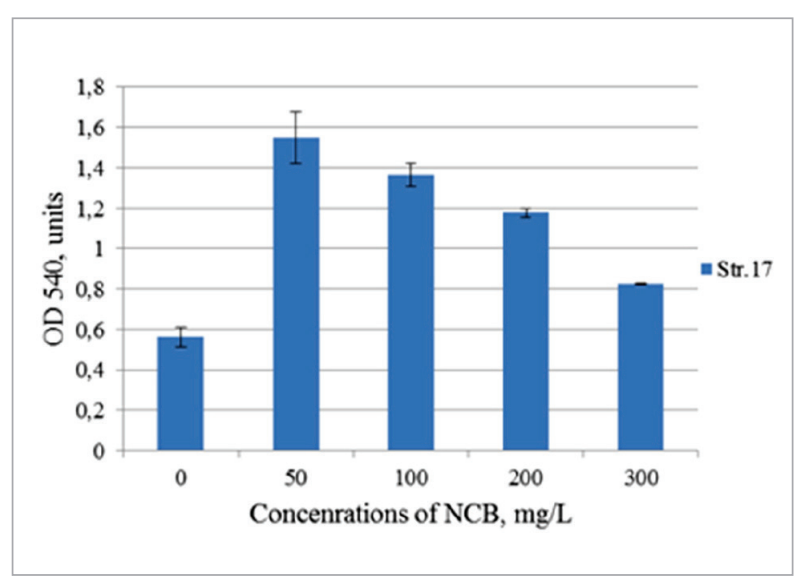

This variation was presented by strains 8 and 17, i.e., Providencia rettgeri and Cupravidus gilardii, respectively. Despite the fact that these bacteria could use NCB as a source of carbon and energy, their high concentrations negatively affected the cell growth. Previously, it was already mentioned that bacteria which utilised nitroaromatic compounds $(0.5 \mathrm{mM})$ as sole source of nitrogen were isolated from soil. With 2,6-dinitrophenol and succinate as carbon source, a Pseudomonas strain was isolated, which liberated and assimilated nitrite. Approximately $2 \mathrm{~mol}$ of NO2- per mol of 2,6-dinitrophenol was released by resting cells. The xenobiotic compound was totally 
degraded, although specific growth yields were low even with succinate as a carbon source (Bruhn et al., 1987). Burkholderia are commonly isolated from plant rhizospheres, and this makes them suitable for rhizoremediation strategies. Rhizoremediation is the degradation of pollutants by rhizosphere bacteria, and indeed root exudation of phenolic compounds has been cited as a possible stimulus for the evolution of aromatic catabolic pathways in some soil bacteria (O'Sullivan \& Mahenthiralingam, 2005).

After the study of resistance of bacteria to NCB, it was also necessary to study the way of NCB transformation and end products. Two pathways are known to destroy NCB: oxidative (aerobic conditions) and reductive (anaerobic conditions):

1 Oxidative pathways require specific for every stochiometric isomers enzymes. It could be illustrated by Pseudomonas stutzeri ZWLR 2-1 strain. This strain uses $o-N C B$ as a sole carbon and energy source and destroys it with the release of chlorine and nitrite ion. During this reaction, -chlorocatechol was defined as the only intermediate product of the 0 -NHB degradation, which was further transformed through chlorocatechol ortho-path with a cleavage of the ring (Arora et al., 2012). The mineralisation of o-NHB strain Pseudomonas putida OCNB-1 was described through the following intermediate products: 2-chloroaniline, 3-chlorocatechol and 3-chloromuconic acid (Haizhen et al., 2009). The enzymes responsible for degradation of o-NHB in the strain OCNB-1 were identified: nitrobenzene reductase, aniline di-oxygenase and catechol-1,2-dioxygenase.
2 The reductive way seems to be more effective. In this case, NCB is used as a non-specific acceptor of electrons. That is why the necessary condition for the transformation process of NCB is the presence of electron donor and the absence of competitive terminal acceptors (oxygen, nitrate). The reaction rate increases with the decreasing medium redox potential. The reduction transformation of $p$-NHB is carried out non-specifically by different types of microorganisms (Grady, 1990):

a aerobic (Nocardia rugosa, Flavobacterium devorans, Bacillus subtilis, Micrococcus roseus);

b facultative anaerobic (Escherichia coli, Enterobacter aerogenes, Pseudomonas aeruginosa);

c obligate anaerobic (Clostridium butyricum, C. acetobutylicum, C. lituseburense).

A diagram of a reductive pathway for NCB isomer destruction by strain $P$. acidovorans CA50 is presented bellow (Fig. 4).

Degradation of NCACs occurs very effectively in anaerobic conditions. There are several stages of this process:

a reduction of a nitro group to an amino group;

b reductive dehalogenation (haloid replacement to hydrogen);

c reduction of a benzolic ring with following cleavage.

For reductive transformation, bacteria need additional sources of carbon and energy. They are used in the preliminary metabolism. The energy source acts as a donor of electrons, and the xenobiotic is an acceptor.

\section{Fig. 4}

The general scheme of anaerobic destruction of NCACs (Fohua \& Siqing, 2011)

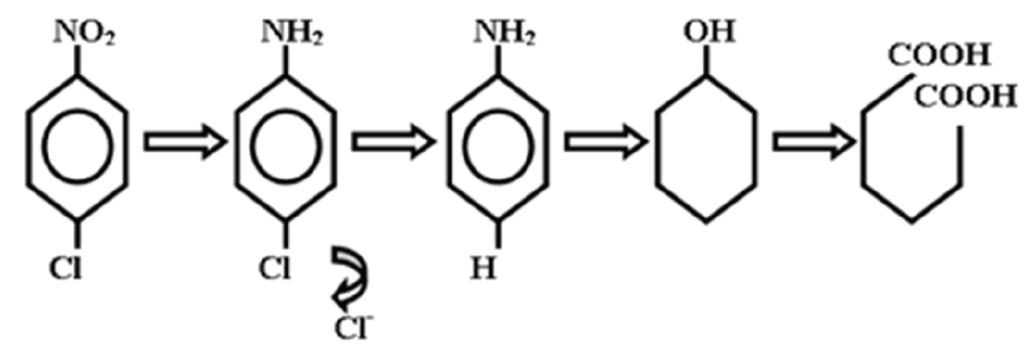


Nitrochloroaromatic xenobiotics are transformed with a reductive method with the formation of non-cyclic compounds (alcohols, fatty acids), which further metabolise by anaerobic microorganisms to methane, $\mathrm{CO}_{2}$ and water (Suslova et al., 2015a; Suslova et al., 2015b; Tahar et al, 2013).

In our case, all studied strains were able to destroy NCB and reduce its concentration in 2 and 3 orders - from 50 and $100 \mathrm{mg} / \mathrm{L}$ to $0.3-0.5 \mathrm{mg} / \mathrm{L}$ in 3 days of cultivation. These results were consistent with literature data about NCB microbial destruction. Thus, for example, an association of Enterobacter cloaceae and Alcaligenes sp. TK-2 was used for the degradation of 4-chloro-2-nitrophenol (4X2NF). Initially, immobilised E. colloaceae cells reduced $4 X 2 N F$ to 4-chloro-2-aminophenol. Then, Alcaligenes sp. TK-2 destructed this compound in aerobic conditions to end products $-\mathrm{CO}_{2}$ and $\mathrm{H}_{2} \mathrm{O}$ (Arora \& Bae, 2014b). In some studied strains $(2,3,5,9,10,11,15,16$ and 17), destruction of NCB proceeded first through transformation of NCB to chloroaniline and later to $\mathrm{CO}_{2}$ and $\mathrm{H}_{2} \mathrm{O}$. Previously, it was shown that rhizospheric Pseudomonas and Sphingomonas strains have genes for polycyclic aromatic compound degradation, which could be used even for industrial purposes (Daane et al., 2001). There is a family of enzymes for ring cleavage of biphenyl, naphthalene and, evidently, for polyaromatic compounds such as dibenzothiophene

\section{References}

Arora, P. K., \& Bae, H. (2014). Toxicity and microbial degradation of nitrobenzene, monochloronitrobenzenes, polynitrobenzenes, and pentachloronitrobenzene. Journal of Chemistry, 2014. https://doi.org/10.1155/2014/265140

Arora, P. K., \& Bae, H. (2014). Biotransformation and chemotaxis of 4-chloro-2-nitrophenol by Pseudomonas sp. JHN. Microbial cell factories, 13(1), 110. https://doi.org/10.1186/s12934-014-0110-7

Arora, P. K., Sasikala, C., \& Ramana, C. V. (2012). Degradation of chlorinated nitroaromatic compounds. Applied microbiology and biotechnology, 93(6), 2265-2277. https://doi.org/10.1007/ s00253-012-3927-1

Bruhn, C., Lenke, H., \& Knackmuss, H. J. (1987). Nitrosubstituted aromatic compounds as nitrogen source for bacteria. Applied and environmental microbiology, 53(1), 208-210.

Daane, L. L., Harjono, I., Zylstra, G. J., \& Häggblom, M. M. (2001). Isolation and characterization of polycyclic aromatic hydrocar- and phenanthrene, containing 3 aromatic rings (Pinyakong et al., 2003). These enzymes have been isolated and described from the proteobacterial genera of Sphingomonas, Pseudomonas, Ralstonia (Cupravidus) and Burkholderia, and from high GC genus of Rhodococcus (Schmalenberger \& Kertesz, 2007). Thus, all these data were the evidence of the fact that the studied bacterial cultures from wheat rhizosphere could degrade nitrochloroaromatic compounds and overcome their toxic effect.

\section{Conclusions}

Isolated from Cd-contaminated soil, rhizospheric bacterial strains were highly resistant to persistent toxic organic nitrochloroamoratic xenobiotic p-nitrochlorobenzene (1-nitro-4-chlorobenzene). Moreover, they could degrade this compound to $\mathrm{CO}_{2}$ and $\mathrm{H}_{2} \mathrm{O}$ using it as additional source of carbon and energy. All studied strains could play a protective role in plant growing and could be used in bioremediation technologies.

\section{Acknowledgements}

We thank Dr. Maksim Kharhota, the head of the laboratory of polymer compounds of Zabolotny Institute of Microbiology and Virology of the NASU for assistance with GC analyses of NCB destruction.

bon-degrading bacteria associated with the rhizosphere of salt marsh plants. Applied and Environmental Microbiology, 67(6), 2683-2691. https://doi.org/10.1128/AEM.67.6.2683-2691.2001

Fohua, L. H. Y. X. Z., \& Siqing, L. J. X. (2011). Experimental study on para-nitrochlorobenzene (p-NCB) removal from groundwater by autohydrogenotrophic microorganism [J]. Chinese Journal of Environmental Engineering, 2, 002.

Grady Jr, C. L. (1990). Biodegradation of toxic organics: status and potential. Journal of Environmental Engineering, 116(5), 805828. https://doi.org/10.1061/(ASCE)0733-9372(1990)116:5(805)

Haizhen, W. U., Chaohai, W. E. I., Yaqin, W. A. N. G., Qincong, H. E., \& Liang, S. (2009). Degradation of o-chloronitrobenzene as the sole carbon and nitrogen sources by Pseudomonas putida OCNB-1. Journal of Environmental Sciences, 21(1), 89-95. https://doi.org/10.1016/S1001-0742(09)60016-4

Katsivela, E., Wray, V., Pieper, D. H., \& Wittich, R. M. (1999). Initial reactions in the biodegradation of 1-chloro-4-nitrobenzene by a 
newly isolated bacterium, strain LW1. Applied and environmental microbiology, 65(4), 1405-1412.

Kovacic, P., \& Somanathan, R. (2014). Nitroaromatic compounds: Environmental toxicity, carcinogenicity, mutagenicity, therapy and mechanism. Journal of Applied Toxicology, 34(8), 810-824. https://doi.org/10.1002/jat.2980

O'Sullivan, L. A., \& Mahenthiralingam, E. (2005). Biotechnological potential within the genus Burkholderia. Letters in applied microbiology, 41(1), 8-11. https://doi.org/10.1111/j.1472-765X.2005.01758.x Pandey J, Heipieper HJ, Chauhan A, Arora PK, Prakash D, Takeo M, Jain RK: Reductive dehalogenation mediated initiation of aerobic degradation of 2-chloro-4-nitrophenol (2C4NP) by Burkholderia sp. strain SJ98. Appl Microbiol Biotechnol. 2011, 92: 597-607. https://doi.org/10.1007/s00253-011-3254-y

Pinyakong O, Habe H, Omori T. (2003). The unique aromatic catabolic genes in sphingomonads degrading polycyclic aromatic hydrocarbons (PAHs). J Gen Appl Microbiol 49: 1-19. https:// doi.org/10.2323/jgam.49.1

Rieger, P. G., Meier, H. M., Gerle, M., Vogt, U., Groth, T., \& Knackmuss, H. J. (2002). Xenobiotics in the environment: present and future strategies to obviate the problem of biological persistence. Journal of Biotechnology, 94(1), 101-123. https://doi. org/10.1016/S0168-1656(01)00422-9

Schmalenberger, A., \& Kertesz, M. A. (2007). Desulfurization of aromatic sulfonates by rhizosphere bacteria: high diversity of the asfA gene. Environmental microbiology, 9(2), 535-545. https://doi.org/10.1111/j.1462-2920.2006.01172.x
Sipilä, T. P., Keskinen, A. K., Åkerman, M. L., Fortelius, C., Haahtela, K., \& Yrjälä, K. (2008). High aromatic ring-cleavage diversity in birch rhizosphere: PAH treatment-specific changes of IE 3 group extradiol dioxygenases and 16S rRNA bacterial communities in soil. The ISME journal, 2(9), 968. https://doi. org/10.1038/ismej.2008.50

Suslova, O. S., Rokitko, P. V., Bondar, K. M., Golubenko, O. O., \& Tashyrev, A. B. (2015). Biochemical mechanisms of resistance to p-nitrochlorobenzene of karst caves microorganisms. The Ukrainian Biochemical Journal, (87,№ 4), 32-36. https://doi. org/10.15407/ubj87.04.032

Suslova, O. S., Rokitko, P. V., Bondar, K. M., Golubenko, O. O., \& Tashyrev, A. B. (2015). Resistance of karst caves microorganisms to p-nitrochlorobenzene. Biotechnologia Acta, 8(4).

Tahar, A., Choubert, J. M., \& Coquery, M. (2013). Xenobiotics removal by adsorption in the context of tertiary treatment: a mini review. Environmental Science and Pollution Research, 20(8), 5085-5095. https://doi.org/10.1007/s11356-013-1754-2

Tomei, M. C., Rossetti, S., \& Annesini, M. C. (2006). Microbial and kinetic characterization of pure and mixed cultures aerobically degrading 4-nitrophenol. Chemosphere, 63(10), 1801-1808. https://doi.org/10.1016/j.chemosphere.2005.10.012

White PM, Wolf DC, Thoma GJ, Reynolds CM. (2006). Phytoremediation of alkylated polycyclic aromatic hydrocarbons in a crude oil-contaminated soil. Water Air Soil Pollut 169: 207-220. https://doi.org/10.1007/s11270-006-2194-0

\section{Rizosperinès bakterijos nitrochloroaromatinių junginių naikinimui}

Gauta: $2018 \mathrm{~m}$. birželis

Priimta spaudai: 2018 m. spalis

\section{lungin 0., Govorukha V., Tashyrev 0.}

Zabolotny institutas mikrobiologija, Nacionalinè mokslų akademija, Kijevas, Ukraina

Nitrochloroaromatiniai junginiai (NCAC) yra vieni iš labiausiai toksišku junginių žmonèms ir sukelia skirtingus sutrikimus, kai jie patenka i maisto grandinę žemès ūkio dirvožemiuose su organinės sintezès imonių nuotekomis. Buvo irodyta, kad mikroorganizmai yra sẻkmingas tokių junginių sunaikinimo būdas. Mūsų tyrimo tikslas buvo patikrinti 17 kviečiu rizosperinių bakteriju padermiu atsparumą ir gebejjimą pažeisti NCAC. Buvo irodyta, nitrochloraromatiniai junginiai yra labai atsparūs 1-nitro-4-chlorbenzenui (NCB) - tipiniam junginiui, kuris jungia neigiamą nitro grupès, chloro ir aromatinio žiedo poveiki. Atsparumo lygis buvo iki $300 \mathrm{mg} / \mathrm{L}$ NCB. Ištirti štamai sugebejo ji pabloginti iki galutiniu produktų (CO2, H2O). Be to, 10 iš 17 bakteriju padermių galejo naudoti 1-nitro-4-chlorbenzeną kaip papildomą anglies ir energijos šaltini.

Raktiniai žodžiai: rizosperinès bakterijos, nitrochloraromatiniai junginiai, degradacija. 